\title{
Possible environmental sources of Acanthamoeba spp in contact lens wearers
}

\author{
David Seal, Fiona Stapleton, John Dart
}

\begin{abstract}
The water supply and dust samples from the home environment (bathrooms and kitchens) of 50 wearers of contact lenses (CLs) were cultured for the presence of free-living amoebae. CL cases, solutions, and water taps were cultured for bacteria, which amoebae require for growth. Acanthamoeba spp were isolated from water drawn from six bathroom cold water taps (tank supplied), five in the presence of limescale, and from one kitchen cold water tap (mains supplied). There was an association between the presence of limescale in water and direct culture for free-living amoebae, suggesting that scale provides a favourable microenvironment for amoebae. Acanthamoebae were also found in dust from around one washbasin. Nineteen of $50 \mathrm{CL}$ cases, 12/122 CL care rinsing solutions, and $59 / 100$ cold water taps yielded Gram negative bacteria which could be ingested by amoebae. It is concluded from this study that CLs should not be washed in first-drawn tank-fed cold water, especially if limescale is present, and that soft CLs should be rinsed in manufactured single-use, sterile solutions. Rigid CL and CL cases should only be washed with boiled tap water (preferably hot), or single-use sterile solutions, and stored $d r y$ to prevent multiplication of amoebae and Gram negative bacteria.
\end{abstract}

Keratitis due to the free-living amoebae, Acanthamoeba polyphaga and $A$ castellanii, occurs mainly in wearers of contact lenses (CLs), ${ }^{1}$ but can also follow corneal trauma, often in rural surroundings. ${ }^{2}$ The majority of patients have worn daily wear soft lenses, ${ }^{3}$ but recent cases have occurred associated with disposable extended wear CLs. ${ }^{45}$ The infection is painful, prolonged, difficult to treat, and can result in blindness. ${ }^{6}$

Acanthamoeba spp have been isolated from environmental sources including well water, hot tub and domestic tap water. ${ }^{17-9}$ Although Acanthamoeba spp are ubiquitous in air, soil, and natural waters the main source of $\mathrm{CL}$ contamination in the UK has remained unclear for most patients. This contrasts with the USA, where the use of home-made saline for disinfecting CLs has been associated with Acanthamoeba keratitis. ${ }^{1}$ A recent study of CL storage case contamination, involving asymptomatic CL wearers, has found Acanthamoeba to be present in seven of 102 cases, of which six also had high bacterial counts. ${ }^{10}$

To investigate possible sources for CL contamination, which is likely to occur prior to infection, 50 persons who wore CLs were visited at home. Samples were collected for isolation of amoebae from their bathrooms and kitchens including dust, the cold water supply, and the washbasin drain. These are the areas in the home where CLs are most likely to be handled. Cold water taps were also cultured for bacteria, as were $\mathrm{CL}$ storage cases and lens care solutions.

\section{Materials and methods}

\section{PATIENTS}

Fifty new patients who presented to the accident and emergency department at Moorfields Eye Hospital, wearing CLs for the correction of low refractive errors, were visited at home. Six had been admitted to the hospital with $\mathrm{CL}$ associated bacterial keratitis. Lens wearers without a problem associated with lens wear $(n=44)$, who attended immediately following a wearer with bacterial keratitis, were identified as a control group.

\section{HOME ENVIRONMENT SAMPLING}

Cold water taps in each patient's bathroom and kitchen were initially sampled by inserting two swabs into each tap. Taps were not pre-heated and run to waste for 2 minutes, which is a standard public health technique to decontaminate the tap and to sample water in the supply pipe, as the requirement was to sample the tap flora likely to be deposited in a CL storage case. Dust in the bathroom was sampled with swabs behind the basin and in adjacent areas. Basin drains were sampled by inserting a swab through the plug hole and rubbing against the inside of the pipe. Swabs were processed for amoebae by placing them on non-nutrient agar seeded with live Escherichia coli washed in phosphatebuffered saline (PBS). Plates were incubated for 1 week at $37^{\circ} \mathrm{C}$ and observed for amoebae under low power microscopy. Identification was made on the basis of morphology and the presence of different types of cysts.

Water samples were collected from bathroom and kitchen cold water taps by drawing off $30 \mathrm{ml}$ of first-run water through the tap, into a sterile bottle. Tap water was not run to waste initially. Thiosulphate was not added to the bottle, to neutralise chlorine in the water, again to simulate conditions in the CL storage cases. Water samples were spun at $2500 \mathrm{rpm}$ for 10 minutes and $0.1 \mathrm{ml}$ of the deposit was inoculated onto non-nutrient agar plates seeded with Escherichia coli, as above. These were incubated at $37^{\circ} \mathrm{C}$ for 1 week. Each sample was observed for the presence of limescale by microscopy of the spun deposit. These water samples were then reinvestigated by a more sensitive enrichment technique, which involved prior incubation of the water with live Escherichia coli for 48 hours. Samples were then 
plated out onto non-nutrient agar and incubated at $37^{\circ} \mathrm{C}$. Different types of amoebae were identified by their morphological appearances.

CL storage cases were sampled with a swab which was rubbed around the inside of the case. These swabs, and others for bacterial culture, plus all lens care materials ( $3 \mathrm{ml}$ of solutions), were cultured on $10 \%$ horse blood, MacConkey, and Sabouraud's agars. Bacteria were identified by standard methods. Patients were questionned as to whether and how CL storage cases were cleaned.

\section{STATISTICAL METHODS}

The $\chi^{2}$ test with Yates correction factor, or Fisher exact test, ${ }^{11}$ where appropriate, was used to analyse the results.

\section{Results}

Table 1 summarises the results for kitchen and bathroom water samples, including the presence of limescale, and culture for amoebae, Acanthamoeba spp, and bacteria. There was good association $(p<0.001)$ between isolation of amoebae by direct culture and the presence of limescale in cold water taps for both the kitchen and the bathroom. However limescale was more frequently found in bathroom taps $(p=0.04)$. Amoebae were found more commonly in the bathroom tap water (tank-fed tap) than in the kitchen water (mains-fed tap), by direct culture $(p<0.05)$. This association was lost when increased numbers of amoebae were recovered using the enrichment technique. Acanthamoeba spp were isolated more frequently $(6 / 50)$ from bathroom water by the enrichment technique compared with kitchen water (1/50). This indicates a trend to growth for amoebae and Acanthamoeba spp in tank-fed water, a warmer environment, and in the presence of limescale. This difference was not statistically significant for Acanthamoeba, probably due to small numbers.

Amoebae and Acanthamoeba spp were not significantly associated with the presence of Gram negative bacteria in either water sample
(Table 1) or tap swabs (data not shown), using direct or enrichment recovery techniques.

Amoebae were isolated from bathroom dust, beside the washbasin, on $6 / 50$ occasions. On one occasion, Acanthamoeba sp was isolated as well.

Amoebae were isolated from the wash-basin drain on 40/50 occasions. Gram negative bacteria were present in 39 samples, of which amoebae were present on 30 occasions. Interestingly, amoebae were isolated from $10 / 11$ samples when Gram negative bacteria were absent. Acanthamoeba spp were isolated on two occasions and Gram negative bacteria were present.

Sixteen CL cases belonging to 44 asymptomatic $\mathrm{CL}$ wearers were contaminated with Gram negative 'coliform' bacteria. Two out of five CL cases belonging to the patients who developed keratitis contained Pseudomonas aeruginosa while one CL case contained 'coliform' bacteria. Such 'coliform' bacteria were also isolated from 12 out of $122 \mathrm{CL}$ care solutions overall. This contamination included 10 out of $108 \mathrm{CL}$ care solutions from 44 asymptomatic CL wearers and two out of 14 solutions from six patients who had developed keratitis.

Results of questioning 35 asymptomatic CL wearers, who were resident at home, revealed that 13 washed their CL cases in tap water of which 11 used bathroom cold water and two used kitchen water. None ran their tap for 2 minutes prior to use but took off the first-drawn water. Fifteen did not clean their CL storage case while seven washed their cases in detergent.

\section{Discussion}

In England the cold water supply to the bathroom is derived from a storage tank in the roof that is rarely drained and cleaned. In contrast, the kitchen cold tap is supplied directly from the mains supply to the house, which later supplies the storage tank. Acanthamoeba spp, thought to be similar to pathogenic strains which infect the cornea, were isolated from 6/50 tank-fed bathroom cold water taps and from 1/50 mains-fed kitchen cold water taps. Isolation of amoebae and Acanthamoeba spp has been described from the water supply of Strasbourg, ${ }^{12}$ which is derived

Table 1 Association of amoebae and bacteria with limescale in kitchen and bathroom tap water

\begin{tabular}{|c|c|c|c|c|c|c|}
\hline \multirow[b]{4}{*}{$\begin{array}{l}\text { Culture } \\
\text { technique }\end{array}$} & \multicolumn{6}{|c|}{ Water samples } \\
\hline & \multicolumn{3}{|c|}{$\begin{array}{l}\text { Bathroom } \\
(\mathrm{n}=50)\end{array}$} & \multicolumn{3}{|c|}{$\begin{array}{l}\text { Kitchen } \\
(\mathrm{n}=50)\end{array}$} \\
\hline & \multicolumn{2}{|c|}{ Limescale } & \multirow[b]{2}{*}{$(p=0.04)^{\star}$} & & \\
\hline & $\begin{array}{l}\text { Present } \\
(\mathrm{n}=32)\end{array}$ & $\begin{array}{l}\text { Absent } \\
(\mathrm{n}=18)\end{array}$ & & $\begin{array}{l}\text { Present } \\
(\mathrm{n}=21)\end{array}$ & $\begin{array}{l}\text { Absent } \\
(\mathrm{n}=29)\end{array}$ & \\
\hline $\begin{array}{l}\text { Direct } \\
\text { Amoebae } \$\end{array}$ & 24 & 0 & $\begin{array}{l}\text { p value } \neq \\
<0.001 \\
\left(\chi^{2}=23\right) \\
(\mathrm{p}=<0.05) \ddagger\end{array}$ & 12 & 1 & $\begin{array}{l}\text { p value } \\
<0 \cdot 001 \\
\left(\chi^{*}=16\right)\end{array}$ \\
\hline $\begin{array}{l}\text { Acanthamoebae } \\
\text { Bacteriaף } \\
\text { (tap swab) }\end{array}$ & $\begin{array}{r}1 \\
19\end{array}$ & $\begin{array}{r}0 \\
13\end{array}$ & NS & $\begin{array}{r}0 \\
11\end{array}$ & $\begin{array}{r}0 \\
14\end{array}$ & $\overline{N S}$ \\
\hline $\begin{array}{l}\text { Enrichment } \\
\text { Amoebae } ₫ \\
\text { Acanthamoeba }\end{array}$ & $\begin{array}{r}29 \\
5\end{array}$ & $\begin{array}{r}15 \\
1\end{array}$ & $\begin{array}{l}\text { NS } \\
\text { NS }\end{array}$ & $\begin{array}{r}17 \\
0\end{array}$ & $\begin{array}{r}17 \\
1\end{array}$ & NS \\
\hline
\end{tabular}


from artesian wells. Free-living amoebae can also be expected to be found in the mains water supply in the UK. Furthermore, cysts of Acanthamoeba spp are relatively resistant to chlorine. ${ }^{13}$

Limescale was found more frequently in water samples drawn from bathroom cold water taps (32/50), compared with samples drawn from kitchen taps (21/50), $p=0 \cdot 04$. By direct culture, there was good association $(p<0.001)$ between the presence of limescale and amoebae, but this association was lost when the enrichment technique was used. Use of the enrichment technique, which allows small numbers of cells to multiply in the water sample prior to culture on agar, demonstrated that in $5 / 6$ bathroom waters and in one mains water sample Acanthamoeba spp were present in low numbers, which could not be detected by direct culture from $0.1 \mathrm{ml}$ of spun deposit derived from a $30 \mathrm{ml}$ sample. There was no statistically significant correlation between the presence of bacteria and amoebae for either kitchen or bathroom samples, nor between bacteria and limescale. We propose that limescale traps the amoebae, which are known to survive in the absence of bacteria, by forming cysts. Small numbers demonstrated in the supplying water could then multiply in the limescale when bacteria are present. It would appear that free-living amoebae can be used as a marker for the possible presence of Acanthamoeba spp but are present from 6-24 times more frequently; Acanthamoba was not isolated in the absence of other amoebae. Our observation that only two cases of Acanthamoeba keratitis have been reported in Scotland (population 5 million). ${ }^{14}$ 15 which has 'soft' water without limescale, is interesting but needs confirmation and comparison with similar situations elsewhere. Both amoebae and Acanthamoeba spp were isolated from the washbasin drains and at a low frequency from the dust in adjacent sites.

Larkin $e t a l^{10}$ found that $43 \mathrm{CL}$ storage cases, used by 102 asymptomatic wearers in an optometric practice, were contaminated by large numbers of bacteria and that seven contained Acanthamoeba spp. This present study has confirmed that CL storage cases from asymptomatic wearers are similarly contaminated with bacteria (16/44) in our population. This implies that CL disinfection in the comminity is ineffective. Furthermore, 12/122 commercial lens care solutions in the home were contaminated with Gram negative bacteria, despite being manufactured to remain sterile. In the USA a similar proportion of asymptomatic lens wearers has been reported as having bacterial contamination of their CL storage cases. ${ }^{16}$

Washing $\mathrm{CL}$ cases with freshly-drawn bathroom cold tap water, in areas using 'hard' water containing limescale, will deposit scale in them which is heavily contaminated with amoebae and bacteria. This scale may inactivate the chemical disinfectant process used. Organic debris has been identified as inactivating chlorine-based CL disinfectant systems. ${ }^{17}$ These observations are consistent with the recent findings that six CL disinfecting solutions were not effective in eliminating Acanthamoeba cysts, from a starting suspension of 100000 , within a reasonable time for clinical use. ${ }^{18}$ Acanthamoeba spp have also been shown to adhere to unworn hydrogel lenses, ${ }^{19}$ which may further reduce the efficacy of chemical disinfectants.

Although a potential source of the organism has been from the lens storage case, two recent cases have been documented associated with the use of disposable extended wear soft lenses, ${ }^{45}$ without the use of lens solution or a lens storage case. This demonstrates that other possible sources of the organism exist. These may include air, ${ }^{20}$ dust such as that in the bathroom, shown in this study, swimming pools, and hot tubs. ${ }^{21}$

Amoebae ingest bacteria and thus good disinfection management involves the removal of both bacteria and amoebae. The findings of this study suggest that freshly-drawn bathroom cold tap water, particularly in 'hard' water areas, should not be used to wash out CL storage cases or to rinse the CLs themselves because of the high contamination rate. It is suggested that CL cases and hard CLs should be rinsed with freshly boiled and cooled water from the domestic kettle. CLs should be cleaned with a surfactant solution prior to disinfection, which should take place in a previously cleaned and dry case, ideally sterile and disposable. After disinfection the CL cases should be rinsed again with hot, boiled water and stored $d r y$ to reduce contamination and multiplication of amoebae and $\mathrm{Gram}$ negative bacteria. It must be accepted from this study and others ${ }^{10}{ }^{16}$ that current use of CL care systems by the general public is not as envisaged by the manufacturers nor as recommended by optometrists.

We are grateful to Melville Matheson, Moorfields Eye Hospital for the analysis of bacterial samples.

This study was supported in part by Fight for Sight, Moorfields locally organised research grants, the Association of Contact Lens Manufacturers, and the British Council for the Prevention of Blindness. F Stapleton was supported by the British College of Optometrists.

We are grateful for assistance with culturing amoebae from Dr $P$ Christie, State Water Laboratory, Melbourne, Australia, Mr S Kilvington, Public Health Laboratory, Bath and Dr D Warhurst, Hospital for Tropical Diseases, London.

1 Stehr Green JK, Bailey TM, Visvesvara GS. The epidemiology of Acanthamoeba keratitis in the United States. Am $\dot{f}$ Ophthalmol 1989; 107: 331-6.

2 Sharma S, Srinivassan M, George C. Acanthamoeba keratitis in non-contact lens wearers. Arch Ophthalmol 1990; 108: 6768.

3 Moore MB, McCulley JP, Newton C, Cobo LM, Foulks GN, O'Day DM, et al. Acanthamoeba keratitis - a growing problem in soft and hard contact lens wearers. Ophthalmology 1987; 94: 1654-61.

4 Ficker L, Hunter P, Seal D, Wright P. Acanthamoeba keratitis occurring with disposable contact lens wear. Am $\mathcal{F}$ Ophthalmol 1989; 108: 453 .

5 Heidemann DG, Verdier DD, Dunn SP, Stamler JF Acanthamoeba keratitis associated with disposable contact Acanthamoeba keratitis associated with dispd

6 Ficker L. Acanthamoeba keratitis - the quest for a better prognosis. Eye 1988; 2: (suppl) 537-45.

7 Harf C, Monteil H. Pathogenic microorganisms in environmental waters: a potential risk for human health. Water In 1989; 14: 75-9.

8 Derr-Harf C. Etude des amibes libres dans les eaux de Strasbourg. PhD Thesis, University Louis Pasteur of Strasbourg, 1977: number 898 .

9 Kilvington S, Larkin DFP, White DG, Beeching JR Laboratory investigation of Acanthamoeba keratitis. $\mathcal{f}$ Clin Microbiol 1990; 28: 2722-5.

10 Larkin DFP, Kilvington S, Easty DL. Contamination of contact lens storage cases by Acanthamoeba and bacteria. $B$ contact lens storage cases by $A$.

11 Siegel S, Castellan NJ, eds. Non parametric statistics for the behavoural sciences. 2nd ed. New York, McGraw-Hill: 1988.

12 behavoural sciences. 2nd ed. New York, McGraw-Hill: 1988. des amibes libres dans les eaux de Strasbourg. Ann Parasitol des amibes libres dans les
(Paris) 1978; 53: 467-77.

13 De Jonkheere J, Van der Woorde H. Difference in destruction 
of cysts of pathogenic and non-pathogenic Naegleria and Acanthamoeba by chlorine. Appl Envir Microbiol 1976; 31 : 294-7.

14 Gibb AB. Acanthamoeba keratitis. Communicable Diseases Scotland 1989; 23: 157.

15 Seal D. Personal communication, 1991

16 Donzis PB, Mondino BJ, Weissman BA, Bruckner DA. Microbial contamination of contact lens care systems. Am $\mathcal{F}$ Ophthalmol 1987; 104: 325-33.

17 Copley CA. Chlorine disinfection of soft contact lenses. Clin Exp Optom 1989; 72: 3-7.
18 Brandt FH, Ware DA, Visvesvara GS. Viability of Acanthamoeba cysts in ophthalmic solutions. Appl Envir Microbiol 1989; 55: 1144-6.

19 John T, Desai D, Sahm D. Adherence of Acanthamoeba castellanii cysts and trophozoites to unworn soft contact
lenses. Am $\mathcal{F}$ Ophthalmol 1989; 108: 658-64.

20 Kingston D, Warhurst DC. Isolation of amoebae from the air f Med Microbiol 1969; 2: 27-36.

21 Samples JR, Binder P, Luibel FJ, Font RL, Visvesvara GS, Peter CR. Acanthamoeba keratitis possibly acquired from a hot tub. Arch Ophthalmol 1984; 102: 707-10 